\title{
Evaluation of the Castability of a Co-Cr-Mo-W Alloy Varying the Investing Technique
}

\author{
Adriana da Fonte Porto CARREIRO \\ Ricardo Faria RIBEIRO \\ Maria da Gloria Chiarello de MATTOS \\ Renata Cristina Silveira RODRIGUES \\ Department of Dental Materials and Prosthodontics, Faculty of Dentistry of Ribeirão Preto, University of São Paulo, \\ Ribeirão Preto, SP, Brazil
}

\begin{abstract}
The purpose of this study was to compare the castability of Co-Cr-Mo-W (Remanium 2000), Ni-Cr (Durabond) and Co-Cr-Mo (Vera PDI) alloys invested with either conventional (phosphate- and silica-based) or mixed investing techniques. A $10 \mathrm{X} 10 \mathrm{~mm}$ squareshaped nylon net containing 100 open squares served as a template for construction of wax patterns, which were invested with phosphate-based investment (Termocast), silica-based investment (Refrafil) and mixed investing technique (2-mm layer phosphate investment plus filling with silica investment). Forty-five cast specimens ( 5 per experimental condition) were obtained and sandblasted with aluminum oxide. The number of completely reproduced cast segments was counted to obtain a percentage designated "castability value", which indicated the accuracy of the alloy to reproduce mold details. Statistical analysis using two-way ANOVA and Tukey's test showed that, comparing the alloys, Remanium 2000 had statistically similar castability ( $>0.05)$ to Vera PDI and lower than Durabond ( $\mathrm{p}<0.05)$. Considering the mixed technique results, Remanium 2000 yielded lower castability value $(\mathrm{p}<0.05)$ than Durabond and Vera PDI alloys, which showed similar results to each other ( $p>0.05$ ). In conclusion, the castability of the Co-Cr-Mo-W alloy (Remanium 2000) was comparable to that of the Co-Cr alloy (Vera PDI) and worse than that of the Ni-Cr alloy (Durabond). Except for Remanium 2000, the mixed investing technique considerably improved the accuracy of the alloys to reproduce cast details, compared to the phosphate-based investment. The mixed investing technique appears as a viable alternative to improve castability of base metal alloys without decreasing the surface quality of the metallic pieces.
\end{abstract}

Key Words: castability, chromium alloys, investing technique.

\section{INTRODUCTION}

Replacement of gold alloys for prosthetic applications has challenged practitioners and researchers alike. Despite the advent of alternative approaches and improvement of the casting process, the results are still unsatisfactory.

Noble alloys were used in metal-ceramics up to the 1960s, at which time the cost of noble metal increased considerably and alternative dental alloys began being developed (1). In addition to a lower cost, metal-ceramic alloys should have good mechanical properties, high flow rate, accurate cast adaptation, ease of handling, finishing and polishing, high corrosion and weld strengths and, above all, biocompatibility (2-4).
Palladium-silver alloys appeared as a promising alternative for gold alloys, exhibiting an intermediary cost, high corrosion strength and satisfactory mechanical properties, which were remarkable advantages over the type III gold alloys available at the time. In spite of these qualities, however, the first palladium-silver alloys caused porcelain staining and had high corrosion, due to oxidation of internal defects or gas absorption during melting (5). With the increase of palladium ratio in these alloys and the improvement of ceramic technology these shortcomings were overcome.

The success of nickel-chromium-cobalt alloys in the fabrication of metal frameworks for removable partial dentures, attributed to their excellent mechanical properties, high corrosion strength, low density and 
reduced cost, stimulated the development of nickelchromium alloys, which have been indicated as a substrate for metal-ceramics since the 1950s. Nevertheless, despite their satisfactory clinical performance and high modulus of elasticity, which give them rigidity even in small thickness, these alloys have limitations related to their high hardness, difficult laboratory processing (6) and low flow rate, the high incidence of incomplete margins being the most frequently reported problem. According to Moffa et al. (7), the increase of casting temperature increases the flow of the alloy and reduces casting failures; nevertheless, it also increases surface roughness, which poses additional difficulty to the finishing and polishing procedures. The further addition of beryllium to nickel-chromium alloys has improved the flow rate considerably. Duncan (8) reported that nickel-chromium-beryllium alloys show better casting than alloys without beryllium, the possible roles of beryllium being to reduce the casting interval, improve casting characteristics, refine the grains of the structure and increase the strength of the alloy.

Bezzon et al. (9) observed that the increase of the amount of beryllium in experimental alloys resulted in better castability and higher strength at the metal/ceramic interface. However, it is common knowledge that beryllium may cause beryliosis, a lung disease resulting from chronic exposition to an environment contaminated with this metal, and therefore special care should be taken while handling beryllium-based alloys.

A cobalt-chromium-molybdenum alloy has recently been introduced to the dental market indicated for metal framework of metal-ceramic dentures. According to its manufacturer, the major advantages of this alloy are its lower thermal expansion coefficient and higher creeping strength in high temperatures during porcelain firing. However, studies have yet to investigate its properties and clinical applicability.

Together with alloy composition, the type of investment and the investing technique have great influence on the final quality of casts. Silica-based investments provide good castability, but the surface quality is pledged by the formation of several nodules. On the other hand, phosphate-agglutinated investments produce excellent superficial quality but have lower castability because the gases are not easily released from the mold. Therefore, the ideal technique should associate the castability of the silica-agglutinated investment and the surface quality produced by phos- phate-agglutinated investment.

Despite the great number of studies investigating the precision of casts, little data are available regarding the effects of cast variables on castability. Therefore, the purpose of this study was to compare the castability of Co-Cr-Mo-W, Ni-Cr and Co-Cr-Mo alloys invested with either conventional (phosphate- and silica-based) or mixed the investing techniques.

\section{MATERIAL AND METHODS}

The tested materials were: Co-Cr-Mo-W (Remanium 2000; Dentaurum, Pforzhein, Germany), Ni-Cr (Durabond; Odonto Comercial Importadora Ltda., São Paulo, SP, Brazil), Co-Cr-Mo (Vera PDI; Aalba Dent. Inc., Cordelia, CA, USA) alloys; phosphatebased (Termocast; Polidental Ind. e Com. Ltda., São Paulo, SP, Brazil) and silica-based (Refrafil QZF-600 FR; Citarc Tecnologia de Minérios Ltda., Campinas, $\mathrm{SP}$, Brazil) investments.

The method used for evaluation of castability was described by Hinman et al. (10). For preparation of each castability pattern, a $10 \times 10 \mathrm{~mm}$ square-shaped nylon net containing 100 open squares was attached to a Y-shaped acrylic matrix and served as a template for construction of a wax pattern. Wax strands $(2 \mathrm{~mm}$ in diameter) were placed along the crossing segments of the nylon net, which formed a $90^{\circ}$ angle at their junctions. The pattern (nylon net plus wax net) was removed from the matrix, isolated with liquid vaseline and placed in a crucible former.

The castability patterns were invested using three different techniques: conventional investing with a phosphate-based investment, conventional investing with a silica-based investment and mixed investing. Investments were proportioned and handled according to the manufacturers' instructions. In the mixed investing technique, a 2-mm layer of phosphate-based investment was first placed (Fig. 1) and, after setting, the mould was filled with silica-based investment. To obtain a standard phosphate investment layer thickness, a silicon matrix was made, previously relieved with two \#7 wax sheets and placed over the nylon/wax net. Control groups consisted of specimens invested in either phosphate- or silica-based investments.

A total of 45 specimens (5 per experimental condition) were melted in acetylene-oxygen flame and injected into the mold by centrifugation. The cast spec- 
imens were sandblasted with aluminum oxide to remove investment residues.

The procedure for assigning a numerical value for castability to the cast specimens was done according to the methodology described by Hinman et al. (10): the square-shaped nylon net provides a grid with 100 open squares and 220 segments. The number of completely reproduced cast segments was counted, divided by 220 and multiplied by 100 to obtain a percentage designated as "castability value". This indicated the accuracy of the alloy to reproduce the wax pattern details. The criterion for determining complete and incomplete segments is illustrated in Figure 2.

Castability data were submitted to statistical analysis using two-way ANOVA and Tukey's test for multiple comparisons at 0.05 significance level.

\section{RESULTS}

Castability values $(\%)$ recorded for each base metal alloy invested with the 3 investing techniques proposed are given in Table 1. Two-way analysis of variance revealed significant differences $(p<0.05)$ for the alloy $\mathrm{x}$ investing technique interaction (Table 1).

Considering the factor investing technique, it was observed that for Durabond and Vera PDI alloys the specimens obtained using the mixed investing tech-

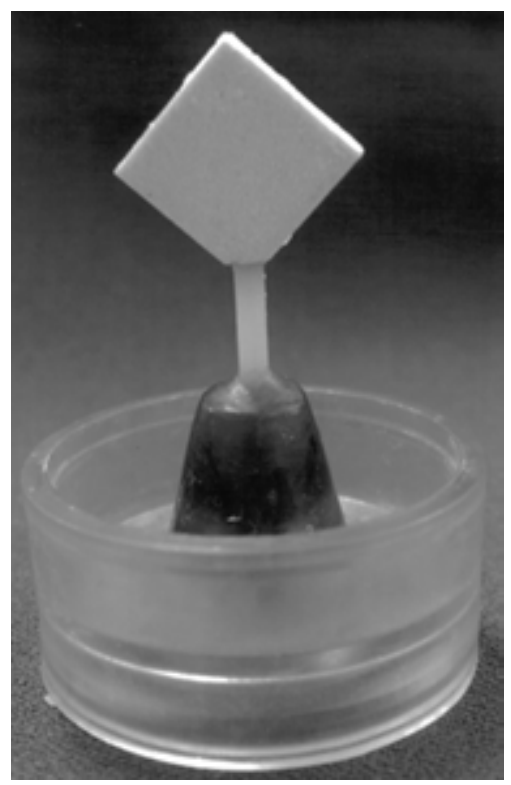

Figure 1. Mixed investing technique. Placement of the phosphatebased investment layer (1st step). nique (Termocast + Refrafil) showed statistically similar castability $(\mathrm{p}>0.05)$ to the specimens invested with Refrafil alone and statistically better castability $(\mathrm{p}<0.05)$ than the specimens invested with Termocast. For Remanium 2000 alloy, specimens obtained using the mixed investing technique showed statistically similar castability $(p>0.05)$ to the specimens invested with Termocast and statistically lower castability value $(p<0.05)$ than the specimens invested with the Refrafil investment. Considering the factor alloy, it was observed that for specimens invested with Termocast investment, Durabond and Remanium 2000 had statistically similar castability $(\mathrm{p}>0.05)$ and both yielded statistically better castability results $(\mathrm{p}<0.05)$ than Vera PDI. For specimens obtained using the mixed investing technique, Remanium 2000 yielded lower castability value $(\mathrm{p}<0.05)$ than Durabond and Vera PDI alloys, which showed similar results to each other $(p>0.05)$. For specimens invested with Refrafil, no statistically significant differences $(\mathrm{p}>0.05)$ were detected among the alloys in terms of castability.

Castability results for the different combinations of alloys and investing techniques are diagrammatically presented in Figure 3.

\section{DISCUSSION}

Since the development of Co-Cr dental alloys, in 1928, and the subsequent introduction of Ni-Cralloys, the applicability of base metal alloys in Prosthodontics has

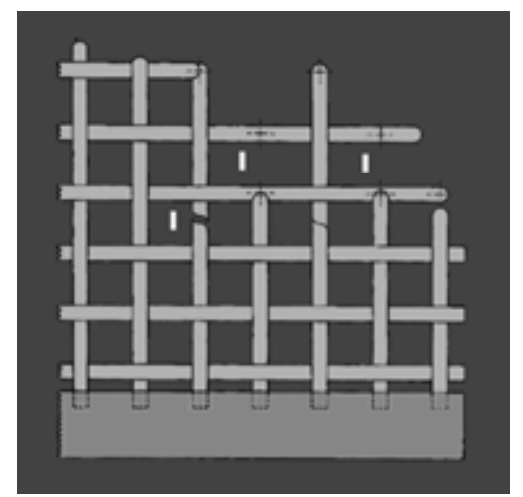

Figure 2. Schematic drawing illustrating the criterion adopted for identification of incomplete casting segments. Segments were considered incomplete if they did not completely extend from the far edge of a crossing segment to the far edge of the next one. Examples of incomplete segments are labeled "I" (Hinman et al., 1985). 
Table 1. Castability values (\%) recorded for each base metal alloy using the 3 investing techniques.

\begin{tabular}{lccc}
\hline & & Investing Technique \\
\cline { 2 - 4 } Alloy & $\begin{array}{c}\text { Termocast } \\
\text { (Phosphate-based investment) }\end{array}$ & $\begin{array}{c}\text { Refrafil } \\
\text { (Silica-based investment) }\end{array}$ & $\begin{array}{c}\text { Termocast + Refrafil } \\
\text { (Mixed technique) }\end{array}$ \\
\hline Remanium 2000 (Co-Cr-Mo-W) & $44.2 \mathrm{Ab}$ & $87.4 \mathrm{Aa}$ & $53.0 \mathrm{Bb}$ \\
Durabond (Ni-Cr) & $57.0 \mathrm{Ab}$ & $100.0 \mathrm{Aa}$ & $98.2 \mathrm{Aa}$ \\
Vera PDI (Co-Cr-Mo) & $26.4 \mathrm{Bb}$ & $91.8 \mathrm{Aa}$ & $83.4 \mathrm{Aa}$ \\
\hline
\end{tabular}

Critical value for 5\% level: 15.29837. Uppercase letters indicate statistical difference for alloys $(\mathrm{p}<0.05)$. Lowercase letters indicate statistical difference for investment technique $(\mathrm{p}<0.05)$.

increased remarkably. Nevertheless, lacks still remain.

Co-Cr-Mo alloys are typically indicated for construction of metal frameworks for removable partial dentures because of their adequate properties, such as good castability, dimensional accuracy, corrosion strength, surface smoothness, low modulus of elasticity and ductility (11).

$\mathrm{Ni}-\mathrm{Cr}$ alloys are currently the most often employed base metal alloys in metal-ceramics, notwithstanding their limitations in terms of castability and creeping strength in high temperatures during porcelain concoction process. Gemalmaz et al. (12) evaluated the changes in marginal adaptation of metal-ceramic dentures after porcelain concoction cycles, in caps made of

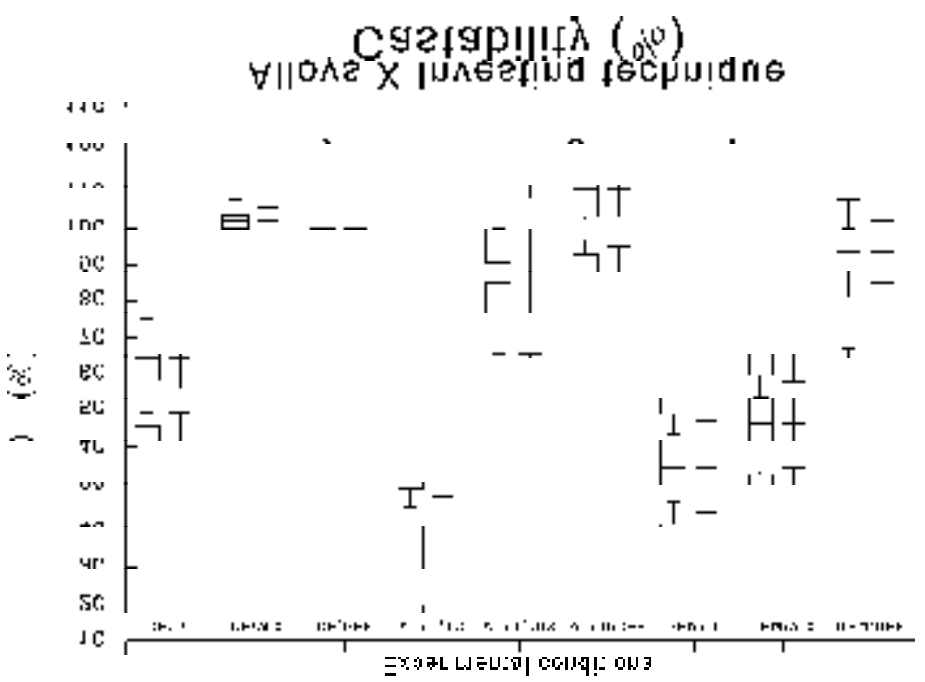

Figure 3. Diagram of the castability results for the different combinations of alloys and investing techniques. $\mathrm{DB}=$ Durabond; $\mathrm{TC}=$ Termocast MIX = Mixed Technique; V-PDI = Vera PDI; REF = Refrafil; REM = Remanium
Ni-Cr (Wiron 99; Bego) and Pd-Cu (Begopal; Bego) alloys and observed greater cervical unfitness after porcelain application.

Therefore, in an attempt to have an alloy that would have higher resistance to creeping in high temperatures and a thermal expansion coefficient closer to that of porcelain, a Co-Cr-Mo-W alloy was developed with the addition of a number of chemical elements in its composition, such as 5\% tungsten, $1.5 \%$ silicon and less than $1 \%$ carbon, manganese and cesium.

In this study, the castability of a Co-Cr-Mo-W alloy (Remanium 2000) was assessed varying the investing technique, and the results were compared to those of $\mathrm{Ni}-\mathrm{Cr}$ (Durabond) and Co-Cr-Mo (Vera PDI) alloys.

Casting aims to provide a copy of the wax pattern as much accurate as possible and thus, castability, defined as the capacity of an alloy to reproduce mold details, is of paramount importance for a successful casting procedure. Nevertheless, a wide range of variables may influence the final result and predicable outcomes are hardly achievable. According to Bessing (13) and Johnson and Winstanley (14), the castability of an alloy may be affected by several factors, including composition, density, surface tension, type of investment, cast temperature, casting machine, positioning of the wax pattern and vent sprue shape. Martignoni and Schönenberger (15) have stated that it is crucial to have knowledge of both the material and the equipment employed in casting, as well as establish a standard casting pattern, according to two basic principles: cast the alloy at the lowest temperature as possible to obtain better physical-mechanical properties; and have a cast alloy flow that fills the mold with maximum 
precision.

The method we used to evaluate castability was first proposed by Whitlock et al. (16) and further employed in several other investigations $(10,11,14,17,18)$. Castability was evaluated by means of cast specimens obtained from a square-shaped wax pattern $(10 \times 10$ $\mathrm{mm}$ ) that provided a grid with 100 open squares. A castability value (percentage) was attributed to the specimens by counting the number of complete segments of the cast grid, which indicated the accuracy of the alloys to reproduce details. Among the advantages of this method are: ease of preparation of the casting pattern; the pattern can be burned out in oven using the usual procedure for wax elimination; size and shape of specimens can be standardized; the casting pattern can be adjusted accordingly to evaluate specific characteristics, depending on the purpose of each study; and castability is evaluated by simply counting the number of completely formed cast segments (10).

In the present study, Remanium $2000(\mathrm{Co}-\mathrm{Cr}$ Mo-W) alloy had a castability value (61.5\%) similar to that of Vera PDI (Co-Cr-Mo) alloy (67.2\%), and both values were lower than that of Durabond $(\mathrm{Ni}-\mathrm{Cr})$ alloy $(85 \%)$. Studies using similar methodology have reached variable outcomes. Jarvis et al. (17) reported a castability value of $76.5 \%$ for Unibond (Ni-Cr) alloy (Unitek Corp.), while O'Connor et al. (19) found a castability value of $53.5 \%$ for Biobond Plus (Ni-Cr) alloy (Dentsply) and $44.6 \%$ for Cobond (Co-Cr) alloy (Dentsply). Although we have found better results with the tested alloys, it is important to point out that several factors influence the final quality of casts, and it is therefore difficult compare our findings to those of other investigations.

The results of this study are in agreement with the typical indications of the tested dental alloys. Because of their high modulus of elasticity and flow capable of copying cast details, $\mathrm{Ni}-\mathrm{Cr}$ alloys are indicated for bridgeworks while $\mathrm{Co}-\mathrm{Cr}$ alloys are better indicated for metal frameworks of removable partial dentures due to their low modulus of elasticity and consequent greater flexibility. The deficiency in reproducing mold details, which is characteristic of this type of alloy, does not result in clinically significant problems. Nevertheless, the results of Remanium 2000 (Co$\mathrm{Cr}-\mathrm{Mo}-\mathrm{W}$ ) alloy were beneath our expectations. Considering that it is indicated for metal-ceramics, it was expected a castability value closer to that of Durabond
(Ni-Cr) alloy, which is also recommended for metalceramic dentures.

It has been shown that the type of investment and the investing technique affect the final quality of casts considerably and the great variety of investments available for dental practice has led a number of researchers to investigate the differences among them. The present study evaluated the influence of a mixed investing technique (a 2-mm-thick layer of phosphate-based investment plus filling of the mold with silica-based investment) on the castability of different alloys. This technique attempts to combine the advantages of two investing materials: the phosphate layer would result in less surface roughness and the silica-based investment would provide better castability because it facilitates gas elimination during the casting process.

Dern et al. (20) evaluated this technique by means of a castability testing. The first layer was vacuum mixed according to the manufacturer's instructions and poured over the specimens. After setting, another investment mixture was prepared using the same powder/ liquid ratio and mixed manually for $45 \mathrm{~s}$ to maximize the integration of air bubbles to the mixture. Control specimens were invested using conventional technique in a single step. No statistically significant differences were found between the tested investing techniques.

The findings of this investigation showed statistically significant differences among the three investing techniques evaluated. The technique with Refrafil silica-based investment had the highest castability percentage (93\%) and the technique with Termocast phosphate-based investment had the lowest castability percentage (42.5\%). The mixed investing technique showed an intermediary castability value (78.2\%). The results revealed that the use of a mixed investing technique increased the castability percentage of the tested alloys. The thin layer of phosphate investment $(2 \mathrm{~mm})$ probably facilitated the release of gases from the mold, which contributed for better castability.

Several factors related to both material and technique employed in investing and casting processes influence the properties of the cast restorations and dentures. Thus, knowing and controlling these factors are important to have predictable outcomes. In the present study, only the variables alloy and investing technique were evaluated and therefore our results should only be compared to those of research conducted using the same methodology. Divergent results 
may be obtained if a different study design is used.

The findings of this in vitro study indicated that, under the tested experimental conditions, the castability of the Co-Cr-Mo-W alloy (Remanium 2000) was comparable to that of the Co-Cr-alloy (Vera PDI) and worse than that of the Ni-Cr alloy (Durabond). Except for Remanium 2000, the mixed investing technique considerably improved the accuracy of the alloys to reproduce cast details, compared to the phosphate-based investing technique. The mixed investing technique appears as a viable alternative to improve castability of base metal alloys without decreasing the surface quality of the metallic pieces.

\section{RESUMO}

O objetivo deste estudo foi comparar a fusibilidade de ligas de Co-Cr-Mo-W (Remanium 2000), Ni-Cr (Durabond) e Co-CrMo (Vera-PDI), incluídas em revestimentos à base de fosfato, sílica ou utilizando uma técnica mista. Uma rede de nylon quadrada (10 X $10 \mathrm{~mm})$ com 100 espaços abertos serviu de modelo para construção de padrões de cera, que foram incluídos com revestimento à base de sílica, revestimento fosfatado e técnica mista (camada de revestimento fosfatado com $2 \mathrm{~mm}$ de espessura + revestimento à base de sílica). Quarenta e cinco espécimes (5 para cada condição experimental) foram fundidos sob chama de gás-oxigênio e a seguir jateados com óxido de alumínio. O número de segmentos fundidos completos foi contado para obter uma percentagem designada como "valor de fusibilidade", representando a precisão da liga em reproduzir os detalhes do molde. A análise estatística por meio de ANOVA a dois critérios e teste Tukey mostrou que, comparando-se as ligas, a Remanium 2000 teve fusibilidade estaticamente semelhante $(p>0,05)$ à da Vera PDI e inferior à da liga Durabond $(p<0,05)$. Considerando os resultados da técnica mista, a liga Remanium 2000 teve menor valor de fusibilidade $(\mathrm{p}<0,05)$ que as ligas Durabond e Vera PDI, que apresentaram valores estatisticamente semelhantes entre si $(p>0,05)$. Concluindo, a fusibilidade da liga de Co-Cr-Mo-W (Remanium 2000) foi comparável à da liga de $\mathrm{Co}-\mathrm{Cr}$ (Vera PDI) e inferior à da liga de Ni-Cr alloy (Durabond). À exceção da liga Remanium 2000, a técnica de inclusão mista aumentou consideravelmente a capacidade das ligas testadas de reproduzir os detalhes do molde, quando comparada à técnica de inclusão em revestimento fosfatado. A técnica de inclusão mista representa uma alternativa para melhorar a fusibilidade de ligas de metais básicos sem afetar a qualidade superficial das peças metálicas.

\section{REFERENCES}

1. Presswood RG, Skjonsby HS, Hopkins G, Presswood TL, Pendleton M. A base metal alloy for ceramo-metal restorations. J Prosthet Dent 1980;44:624-629.

2. Hesby DA, Kobes P, Garver DG, Pelleu GB Jr. Physical properties of a repeatedly used nonprecious metal alloy. J
Prosthet Dent 1980;44:291-293.

3. Nelson DR, Palik JF, Morris HF, Comella MC. Recasting a nickel-chromium alloy. J Prosthet Dent 1986;55:122-127.

4. Tjan AHL, Logan GI, Baum L. Marginal accuracy of complete crowns made from alternative casting alloys. J Prosthet Dent 1991;66:157-164.

5. Oilo G, Holland RI, Johansen OA. Porosities in a dental silverpalladium casting alloy. Acta Odontol Scand 1985;43:9-13.

6. Weiss PA. New design parameters: utilizing the properties of nickel-chomium superalloys. Dent Clin North Am 1977;21:769785 .

7. Moffa JP, Lugassy AA, Guckes AD, Gettleman L. An evaluation of nonprecious alloys for use with porcelain veneers. Part I. Physical properties. J Prosthet Dent 1973;30:424-431.

8. Duncan JD. The casting accuracy of nickel-chromium alloys for fixed prostheses. J Prosthet Dent 1982;47:63-68.

9. Bezzon OL, Mattos MGC, Ribeiro RF, Rollo JMDA. Effect of beryllium on the castability and resistance of ceramometal bonds in nickel-chromium alloys. J Prosthet Dent 1998;80:570-574.

10. Hinman RW, Tesk JA, Whitlock RP, Parry EE, Durkowski JS. A technique for characterizing casting behavior of dental alloys. J Dent Res 1985;64:134-138.

11. Hero H. Effects of casting temperature on some properties of CoCr-Mo dental casting alloys. Acta Odontol Scand 1984;42:371377.

12. Gemalmaz D, Alkumru HN. Marginal fit changes during porcelain firing cycles. J Prosthet Dent 1995;73:49-54.

13. Bessing C. Evaluation of the castability of four different alternative alloys by measuring the marginal sharpness. Acta Odontol Scand 1986;44:166-172.

14. Johnson A, Winstanley RB. The evaluation of factors affecting the castability of metal ceramic alloy-investment combinations. Int J Prostodont 1996;9:74-78.

15. Martignoni M, Schönenberger A. Precision Fixed Prosthodontics: Clinical and Laboratory Aspects. Chicago: Quintessence Pub. Co.; 1990

16. Whitlock RP, Hinman RW, Eden GT, Tesk JA, Dickson G, Parry EE. A practical test to evaluate the castability of dental alloys. J Dent Res 1981;60:404.

17. Jarvis RH, Jenkins TJ, Tedesco LA. A castability study of nonprecious ceramometal alloys. J Prosthet Dent 1984;51:490494.

18. Cohen SM, Kakar A, Vaidyanathan TK, Viswanadhan T. Castability optimization of palladium based alloys. J Prosthet Dent 1996;76:125-131.

19. O'Connor RP, Marckert Jr. JR, Myers ML, Parry EE. Castability, opaque masking, and porcelain bonding of 17 porcelain-fused-tometal alloys. J Prosthet Dent 1996;75:367-374.

20. Dern WM, Hinman RW, Hesby RA, Pelleu GB. Effect of a twostep ringless investment technique on alloy castability. J Prosthet Dent 1985;53:874-876. 